\title{
Two new species and a new distributional record of Alterosa (Trichoptera: Philopotamidae) from southeastern Brazil
}

\author{
Christina Novais ${ }^{1,2}$; Leandro Lourenço Dumas ${ }^{1,3}$ \& Jorge Luiz Nessimian ${ }^{1,4}$ \\ ${ }^{1}$ Universidade Federal do Rio de Janeiro (UFRJ), Instituto de Biologia (IB), Departamento de Zoologia, Laboratório de Entomologia. \\ Rio de Janeiro, RJ, Brasil. \\ ${ }^{2}$ ORCID: http://orcid.org/0000-0003-0216-8766. E-mail: christinanovais5@gmail.com \\ 3 ORCID: http://orcid.org/0000-0002-6590-3388. E-mail: Ildumas82@gmail.com \\ ${ }^{4}$ ORCID: http://orcid.org/0000-0001-8795-2538. E-mail:jnessimian@gmail.com
}

\begin{abstract}
The genus Alterosa Blahnik (2005), with 39 extant species, is endemic to Atlantic Forest areas of southern and southeastern Brazil. Herein, we describe and illustrate two new species from Rio de Janeiro state, southeastern Brazil: Alterosa cornuta sp. nov., easily diagnosed by the horn-like intermediate appendages crossing each other, and $A$. araras sp. nov., recognized mainly by the extremely developed basodorsal protuberance on tergum $X$ and by the rod-like, mesally curved preanal appendages, with at least 2 stout spine-like setae positioned at mid length and with the apex cupped. Additionally, a new distributional record for Espírito Santo state, southeastern Brazil, is provided for Alterosa falcata Blahnik (2005).
\end{abstract}

Key-Words. Atlantic Forest; Distributional notes; Finger-net caddisflies; Neotropics; Taxonomy.

\section{INTRODUCTION}

Philopotamidae is a worldwide caddisfly family with 22 extant genera and approximately 1,300 described species distributed into three subfamilies: Rossodinae, with 16 species in the genus Rossodes Özdikmen \& Darilmaz (2008); the cosmopolitan Chimarrinae, with about 800 extant species distributed into three genera; and Philopotaminae, with more than 400 described species within 18 genera (Blahnik, 2005; Özdikmen \& Darilmaz, 2008; Gibon, 2013; Holzenthal et al., 2018). Most of the Philopotaminae genera have relatively restricted distribution (Holzenthal et al., 2007). Five genera are recorded in Neotropical region: Wormaldia McLachlan (1865), with about 200 species in all biogeographic regions except Australasian (50 of them occur in Neotropics); Hydrobiosella Tillyard (1924), with about 30 species in Australasia and one species from the Andes of Ecuador; the monotypic Aymaradella Holzenthal, Blahnik \& Ríos-Touma (2018), restricted to the Bolivian Andes; Sortosa Navás (1918), with 20 extant species restricted to southern Chile and adjacent regions of Argentina; and Alterosa Blahnik (2005), endemic to Brazil with 39 described species (Blahnik, 2005; Muñoz-Quesada \& Holzenthal, 2015; Holzenthal \& Calor, 2017; Holzenthal et al., 2018).
Alterosa was erected by Blahnik (2005) to include two previously described species Dolophilodes (Sortosa) sanctipauli Flint (1971) and Dolophilodes (Sortosa) marinonii Almeida \& Duarte (2003) and 20 new species. Since then, several species have been described, almost doubling the number of species in the genus (Jardim \& Dumas, 2012; Dumas \& Nessimian, 2013; Dumas et al., 2013; Barcelos-Silva et al., 2015). Adults are medium-sized, dark-brown in overall color, and can be recognized by features of male genitalia, such as the phallobase structure, which is tubular basally lacking a basodorsal expansion, common in most philopotamids (Blahnik, 2005). They are usually found in pristine headwaters and rapids of streams or small rivers in Atlantic Forest, but are not common in large rivers (Jardim \& Dumas, 2012; Dumas \& Nessimian, 2013). Despite the several new species described in the genus in the last few years, the diversity of species is still apparently underestimated. There is also a lack of information about its ecology, distribution and biology, especially about its immature stages, which remain unknown.

In the present paper, two new species of Alterosa are described and illustrated from male specimens collected in Rio de Janeiro state, southeastern Brazil. Also, a new geographic record is provided for Alterosa falcata Blahnik (2005), reported here to Espírito Santo state. 


\section{MATERIAL AND METHODS}

The specimens were collected near pristine streams in Atlantic Forest areas of two municipalities of Rio de Janeiro state - Petrópolis and Rio Bonito (Fig. 1) using Pennsylvania light trap (Frost, 1957) and Malaise trap (Gressit \& Gressit, 1962). The collected material was preserved in $96 \%$ ethanol. Length of forewing was measured from base to apex and is presented as a range followed by the number of specimens measured. To better observe and illustrate the genital structures, the abdomen was removed and cleared in a heated solution of $85 \%$ acid lactic (Blahnik et al., 2007), being mounted on a temporary slide with glycerin jelly. After that, removed abdomens were stored permanently in micro vials with $96 \%$ ethanol, with the rest of the respective body. Pencil sketches of genital structures were illustrated using a Carl Zeiss compound light microscope (model Axiolab) equipped with camera lucida and then scanned and used as templates to trace graphic vectors in the program Adobe Illustrator CS6. The terminology used in the descriptions follows that of Blahnik (2005). The holotypes and paratypes are deposited in Coleção Entomológica Professor José Alfredo Pinheiro Dutra, Departamento de Zoologia, Universidade Federal do Rio de Janeiro (DZRJ), Rio de Janeiro state, Brazil.

\section{TAXONOMY}

\section{Alterosa araras, new species (Figs. 2A-2D)}

Diagnosis: Alterosa araras sp. nov. clearly belongs to guapimirim group, as defined by Blahnik (2005), and shares many similarities with A. guapimirim Blahnik (2005) and A. orgaosensis Blahnik (2005). All of them have a similarly developed, bulbously enlarged tergum $\mathrm{X}$, with a basolateral projection; similar preanal appendages with a cupped apex bearing a spine-like seta; and similarly shaped inferior appendages, with second articles much shorter than the first. The new species resembles A. guapimirim in having sclerotized intermediate appendages, with several spines apically, but they are shorter and less developed in $A$. araras sp. nov. than in A. guapimirim. Alterosa araras sp. nov. also resembles $A$. orgaosensis in the shape of the preanal appendages, which are thinner in both species, as viewed laterally, than those of A. guapimirim. However, in the new species they have an extra stout, spine-like seta at midlength, absent in both A. orgaosensis and A. guapimirim. Additionally, A. araras sp. nov. can be distinguished from both by the general shape of tergum $X$, especially by its much more well-developed basolateral projection.

Description: Adult: Color (in alcohol) golden-brown; legs, palps, and antennae pale-brown, forewing color pattern not discernible. Male forewings $7.20 \mathrm{~mm}(\mathrm{n}=10$; holotype $=7.20 \mathrm{~mm}$ ). Maxillary palps 5-articulated; $2^{\text {nd }}$ article with elongate setae at apicomesal portion; $3^{\text {rd }}$ article about $2 x$ length of $2^{\text {nd }} ; 5^{\text {th }}$ article elongate, about $2.5 x$ length of $3^{\text {rd }}$. Head setal warts well-developed, frontal setal warts large, rounded; anteromesal setal warts laterally fused to anterior setal wart, M-shaped; posterior setal wart subtriangular; posterolateral setal warts large, robust and about ovoid. Tibial spurs formula: 2-4-4. Wing venation typical for the genus; forewings with forks I-V present, discoidal and thyridial cells similar in length; hind wings with forks I-III and V presents.

Male genitalia: Tergum VIII posteromesal margin with a shallow U-shaped emargination/incision. Sternum IX with anterolateral margin forming a moderately rounded projection in dorsal half; posteroventral margin slightly produced, forming broadly rounded expansion (Fig. 2A). Tergum IX reduced, forming a mesal projection over base of tergum $\mathrm{X}$, projection prominent, apex subtruncate in lateral view and rounded, subspatulate as viewed dorsally (Fig. 2B). Tergum $X$ with lateral margins sinuous in lateral view, subparallel as viewed dorsally, apex rounded and sensillate, forming greatly enlarged expansion in apical half as viewed laterally; dorsally with longitudinal mesal ridge, well-developed and slightly crenulated as viewed laterally (Figs. 2A, 2B); tergum basolaterally with well-developed setose projection, foot-like, placed in a large, sclerotized concave depression (Figs. 2A, 2B). Intermediate appendages about half length of preanal appendages, rod-like, strongly sclerotized; apex with several apical spines (Figs. 2A, 2B). Preanal appendages elongate, narrow and mesally curved; apex and mesal portion both with a single spine-like seta in a concavity (left appendage with an extra subapical small spinelike seta in holotype) (Figs. 2A, 2B). Inferior appendages setose, elongate, about linear, flattened on mesal surface; first article, laterally, approximately 2 times as long as wide; second article shorter than first (less than half length), base narrower than apex of first article, slightly constricted mesally, apex rounded with prominent pad of short, stiff apicomesal setae (Figs. 2A, 2C). Phallobase elongate and tubular, strongly curved near middle; endotheca with paired spines -2 apical pairs and 1 basal pair very large and curved - and 2 isolated spines.

Holotype male: BRAZIL: Rio de Janeiro: Petrópolis, Araras, REBIO Araras, Rio Araras, Trilha do Caneco (ponte), $22^{\circ} 26^{\prime} 13.8^{\prime \prime} \mathrm{S}, 43^{\circ} 15^{\prime} 37.4^{\prime \prime} \mathrm{W}, 17 . x i-13 . x i i .2018,1,086 \mathrm{~m}, \mathrm{C}$ Novais, LL Dumas, JL Nessimian \& AA Alves leg. (DZRJ).

Paratypes: BRAZIL: Rio de Janeiro: same data as holotype, 4 males (DZRJ); same locality as holotype, 20.iii-13.iv.2018, C Novais, LL Dumas, JL Nessimian \& ALD Ferreira leg., 2 males (DZRJ); same locality as holotype, 13.iv-07.v.2018, C Novais, LL Dumas, JL Nessimian \& ALH Oliveira leg., 1 male (DZRJ); Petrópolis, Araras, REBIO Araras, Rio Araras, Trilha do Caneco (acima da captação de água), $22^{\circ} 26^{\prime} 15.8^{\prime \prime}$ S, 4315'37.7"W, 13.iv.2018, 1,104 m, C Novais, LL Dumas, JL Nessimian \& ALD Ferreira leg., 1 male (DZRJ); Petrópolis, Araras, REBIO Araras, Rio Araras, trilha da represa (pequena cachoeira acima da gruta), 22 $26^{\prime} 19.1^{\prime \prime} \mathrm{S}, 43^{\circ} 15^{\prime} 40.9^{\prime \prime} \mathrm{W}$, 13.xii.2018, 1,124 m, 
AA Alves leg., 5 males (DZRJ); Petrópolis, Araras, REBIO Araras, Rio Araras, trilha da represa (pequena cachoeira acima da gruta), $22^{\circ} 26^{\prime} 19.1^{\prime \prime} S, 43^{\circ} 15^{\prime} 40.9^{\prime \prime} \mathrm{W}, 14 . x i i .2018$, 1,124 m, C Novais, LL Dumas, JL Nessimian \& AA Alves leg., 11 males (DZRJ); Petrópolis, Araras, REBIO Araras,

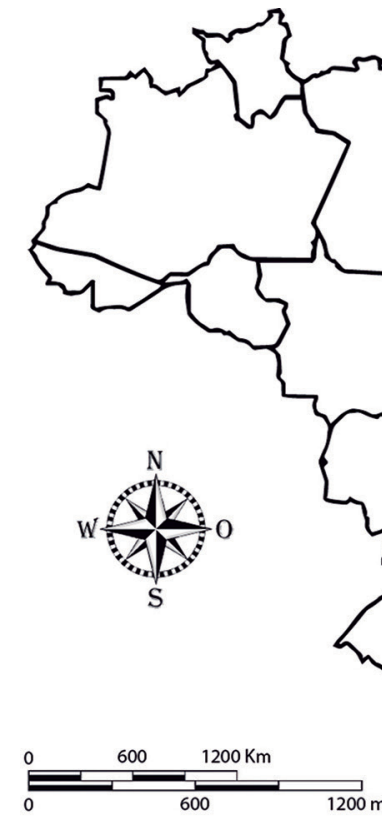

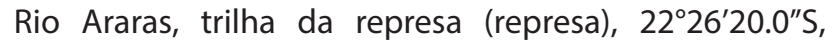
4315'42.4"W, 14.xii.2018, 1,123 m, C Novais, LL Dumas, JL Nessimian \& AA Alves leg., 2 males (DZRJ).

Distribution: Brazil (RJ).

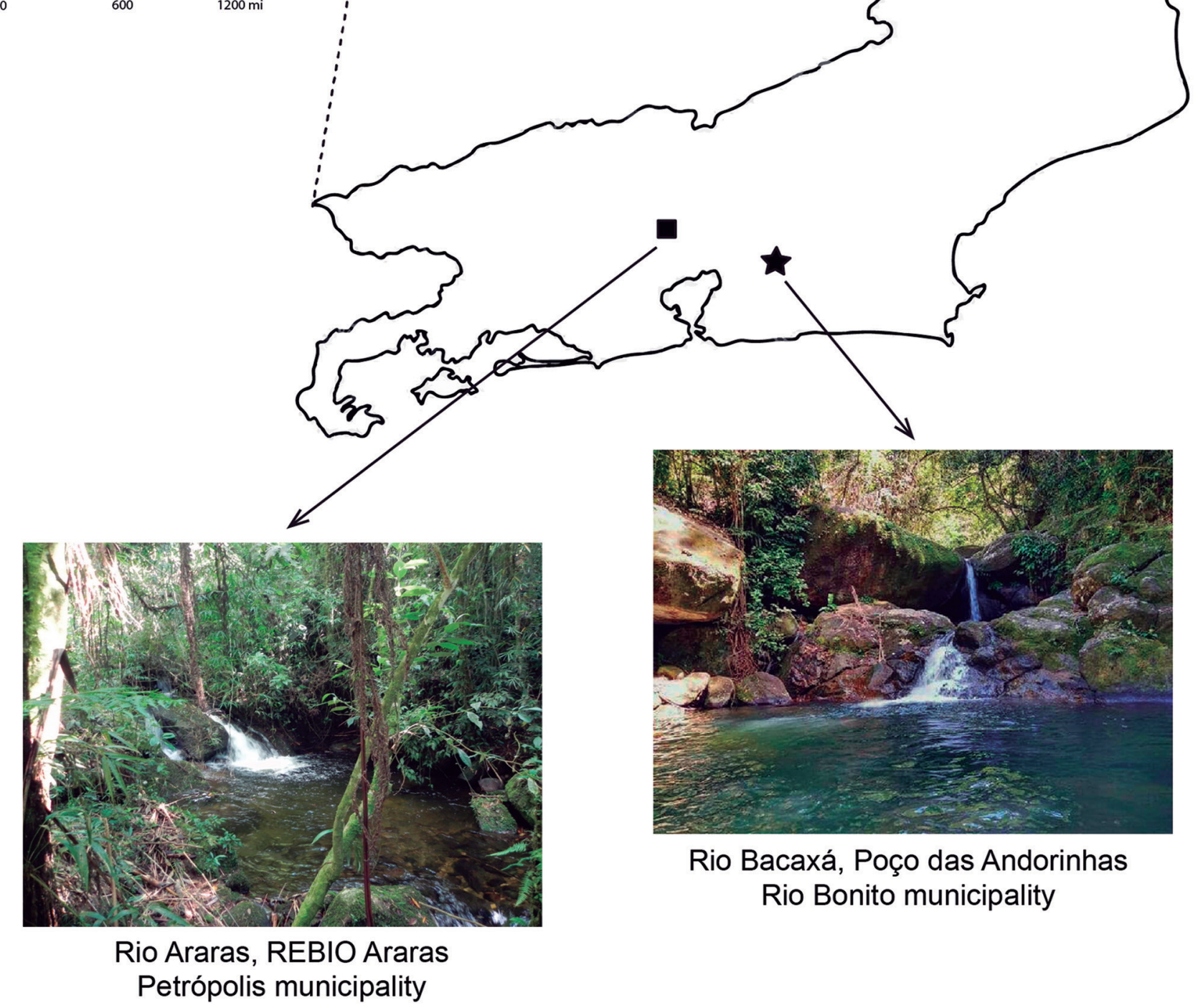

Figure 1. Distributional map and type localities of Alterosa araras sp. nov. and A. cornuta sp. nov. 
Etymology: The new species is named araras (a noun in apposition) in allusion to the Reserva Biológica de Araras, a beautiful Atlantic Forest reserve where the types specimens were collected.
Remarks: Alterosa araras sp. nov. is very similar and probably closely related to $A$. guapimirim and $A$. orgaosensis. Blahnik (2005) in the original descriptions of A. guapimirim and A. orgaosensis claimed that it is possi-
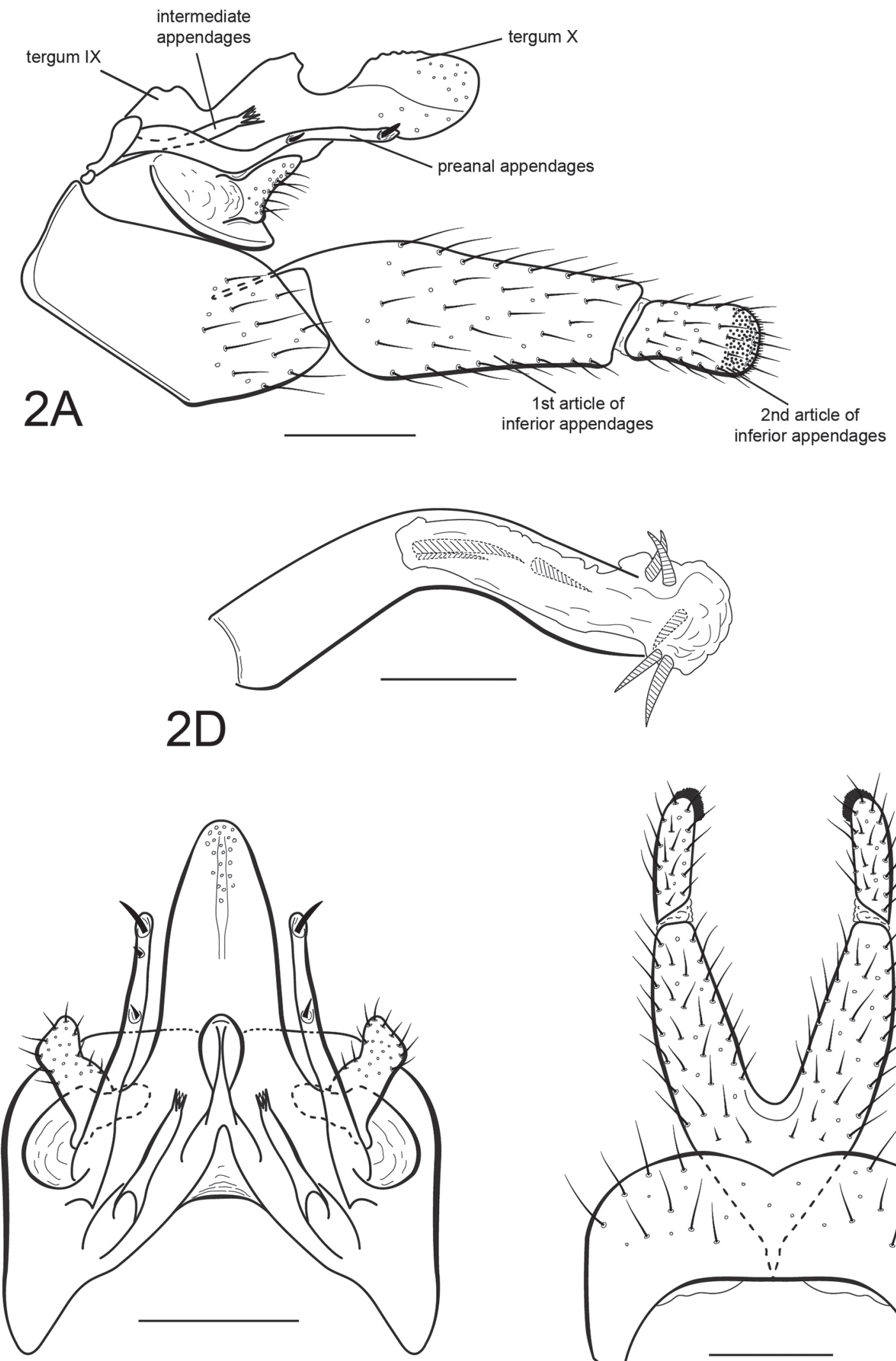

2B

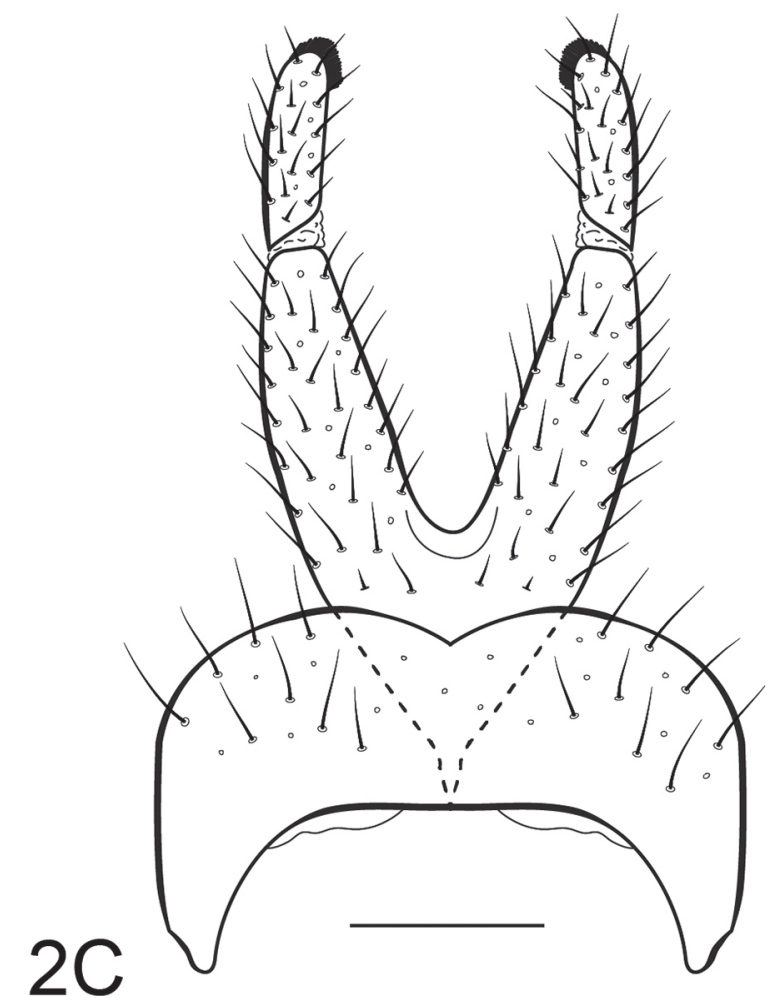

Figure 2. Alterosa araras, new species, male genitalia. (A) lateral view; (B) dorsal view; (C) ventral view; (D) phallic apparatus, left lateral view. Scale =0.25 mm.. 
ble that the two species may eventually prove to be not specifically distinct. We therefore carefully examined and compared $A$. araras sp. nov. with the holotypes of previous described species, which are deposited in Museu de Zoologia de São Paulo (MZSP), choosing describe it as a new species. The new species can be recognized based on morphology of male genital structure, as discussed above. We think that these species represent a
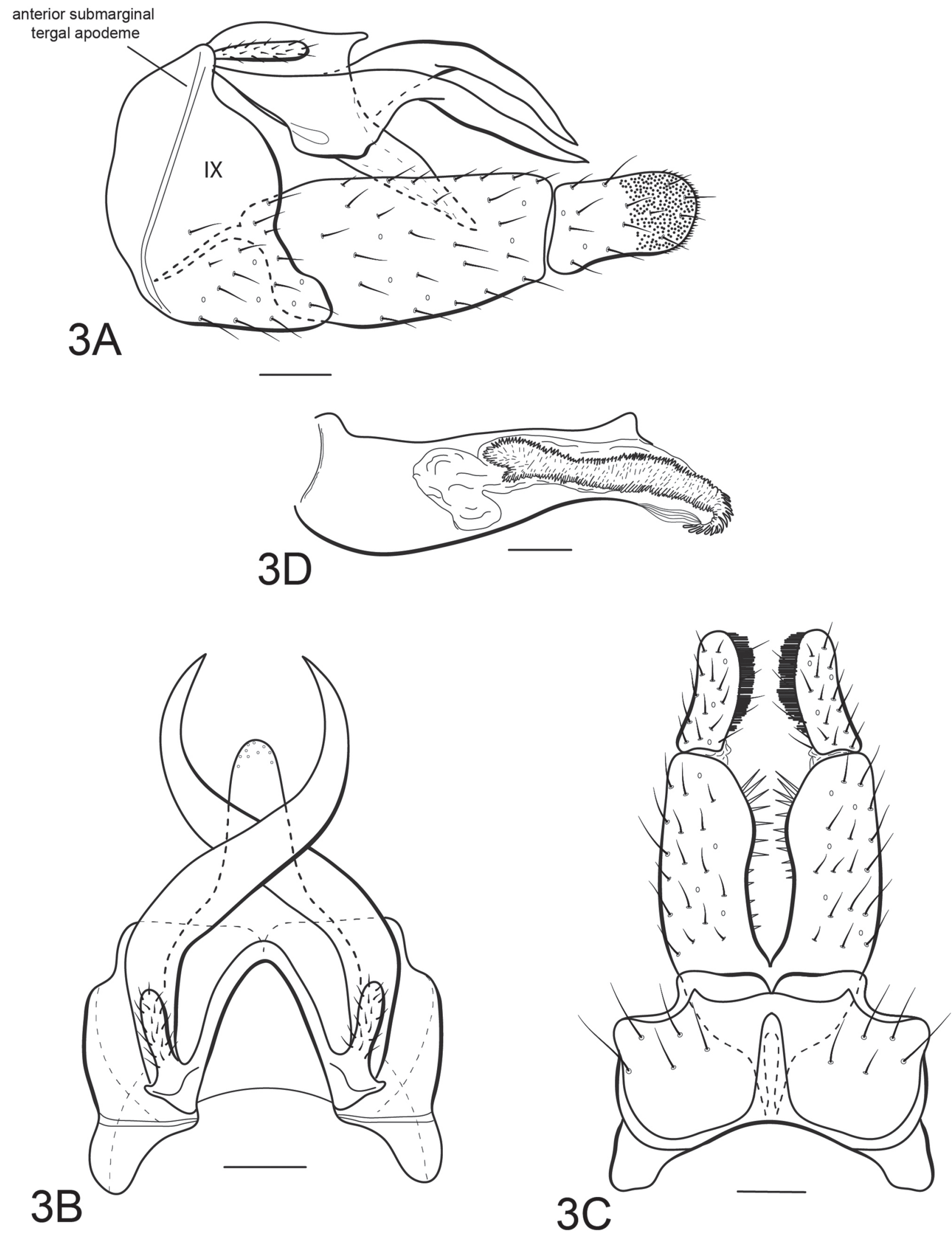

Figure 3. Alterosa cornuta, new species, male genitalia. (A) lateral view; (B) dorsal view; (C) ventral view; (D) phallic apparatus, left lateral view. Scale $=0.10 \mathrm{~mm}$. 
species complex, possibly contemporaneously diverged. However, further studies using analysis of DNA sequence may be useful in determining whether they form a species complex or whether they are a single polymorphic species.

\section{Alterosa cornuta, new species}

(Figs. 3A-3D)

Diagnosis: Alterosa cornuta sp. nov. is distinctive within the genus and cannot be easily placed in any of the species groups defined by Blahnik (2005). However, the new species share similarities with $A$. guapimirim Blahnik (2005) and A. orgaosensis Blahnik (2005), regarding the general structure of the inferior appendages, with first article less than half length of the second. Alterosa cornuta sp. nov. is easily diagnosed by the overall shape of the intermediate appendages with the apical half hornshaped and crossing each other over the apical half of tergum $X$, with each appendage slightly turned ventrad. Additionally, the inferior appendages each have a row of large spine-like setae on the inner margins that decrease in size to the base, which is also asymmetric on the right and left sides. Also, the endotheca has a tongue-like spinous plate, that differs from all others species of the genus.

Description: Adult: Color (in alcohol) golden-brown; legs, palps, and antennae pale-brown, forewing color pattern not discernible. Male forewings 6.24-7.20 mm $(\mathrm{n}=6$; holotype $=6.40 \mathrm{~mm}$ ). Maxillary palps 5-articulated; $2^{\text {nd }}$ article with elongate setae at apicomesal portion; $3^{\text {rd }}$ article about $2 x$ length of $2^{\text {nd }} ; 5^{\text {th }}$ article elongate, about $3.5 x$ length of $3^{\text {rd }}$. Head setal warts well-developed, frontal setal warts large, rounded; anteromesal setal warts laterally fused to anterior setal wart M-shaped; posterior setal wart rounded; posterolateral setal warts large, robust and about ovoid. Tibial spurs formula: 2-4-4. Wing venation typical for the genus; forewings with forks I-V present, discoidal and thyridial cells similar in length; hind wings with forks I-III and V present.

Male genitalia: Tergum VIII with posteromesal margin rounded, not emarginate. Sternum IX with anterolateral margin moderately rounded; posteroventral margin sinuous, slightly produced; anterior submarginal tergal apodeme well-developed (Fig. 3A). Tergum IX greatly reduced, membranous or fused to base of tergum $X$ (Fig. 3A). Tergum $X$ subtriangular in lateral and dorsal views, bent ventrad, tapering to apex (Figs. 3A, 3B); laterally with a mesal triangular dorsal projection on the basal third, apex subacute (Fig. 3A); in dorsal view strongly tapering to apex from apical half, apex rounded (Fig. 3B). Intermediate appendages sclerotized, very elongate, base large, trapezoidal, horn-shaped, between 4-5 times longer than preanal appendages, with a hookshaped mark ventrobasally; both slightly turned ventrad and crossing each other over the apical half of the tergum $X$ (Figs. 3A, 3B). Preanal appendages moderately elongate, club-shaped, covered with small setae; apex rounded (Figs. 3A, 3B). Inferior appendages elongate, linear, flattened on mesal surface; first articles, laterally, approximately 2 times as long as wide, each ventrally with a row of large spine-like setae on inner margins, setae decreasing in size to base (asymmetric in right and left sides); second article shorter than first (less than half length), base narrower than apex of first article, slightly constricted mesally; apex rounded with prominent pad of short, stiff apicomesal setae (Figs. 3A, 3C). Phallobase tubular, moderately elongate, with slight curvature near apex; endotheca with a large sclerotized spinous plate, tongue-like, resembling a molluscan radula (Fig. 3D).

Holotype male: BRAZIL: Rio de Janeiro: Rio Bonito, Lavras, Rio Bacaxá, acima do Poço das Andorinhas, $22^{\circ} 39^{\prime} 40.4^{\prime \prime} \mathrm{S}, 42^{\circ} 36^{\prime} 04.4^{\prime \prime} \mathrm{W}$, 22.x.2017, $267 \mathrm{~m}$, LL Dumas \& JL Nessimian leg. (DZRJ).

Paratypes: BRAZIL: Rio de Janeiro: same data as holotype, 3 males, 2 females (DZRJ).

Distribution: Brazil (RJ).

Etymology: The specific epithet of this species comes from the Latin word cornuta (horn), in allusion to the horn-shaped intermediate appendages.

\section{NEW DISTRIBUTIONAL RECORD}

\section{Alterosa falcata Blahnik (2005)}

Although most species of the genus Alterosa have fairly restricted distributions in pristine Atlantic Forest streams, A. falcata Blahnik (2005) can be considered one of the few exceptions. Originally described from several locations in Minas Gerais, Rio de Janeiro and São Paulo states (Blahnik, 2005), its distribution was extended to other areas of these states (Dumas et al., 2009; Dumas \& Nessimian, 2012). Herein, we record this species for the first time from Espírito Santo state, southeastern Brazil.

Material examined: BRAZIL: Espírito Santo: Santa Teresa, EB de Santa Lucia, afluente de $1^{\text {a }}$ ordem do Rio Timbui, 1957'57.2"S, 40³2'16.4"W, 21.iii.2013, 653 m, LL Dumas \& JL Nessimian leg., 1 male (DZRJ).

Distribution: Brazil (RJ, SP, MG, ES [new record]).

\section{ACKNOWLEDGMENTS}

We would like to thank all members of Laboratório de Entomologia (UFRJ) that assisted with the collection of specimens and the team of Reserva Biológica de Araras (REBIO Araras) for support during field work. We are grateful to Dra. Eliana Cancello and Dr. Carlos Campaner for the support in Museu de Zoologia de São Paulo. We also thank the Instituto Estadual do Ambiente 
(INEA; permit № 038/2014) for issuing collecting permit. This study was financed in part by the Coordenação de Aperfeiçoamento de Pessoal de Nível Superior - Brasil (CAPES) - Finance Code 001, Fundação Carlos Chagas Filho de Amparo à Pesquisa do Estado do Rio de Janeiro (FAPERJ) and Conselho Nacional de Desenvolvimento Científico e Tecnológico (CNPq) p. 420573/2016-0 and 440472/2015-6.

\section{REFERENCES}

Almeida, G.L. \& Duarte, M. 2003. A new species of Dolophilodes (Sortosa) Navás (Trichoptera: Philopotamidae) from Brazil. Proceedings of the Entomological Society of Washington, 105(4): 967-969.

Barcelos-Silva, P.; Dumas, L.L. \& Pes, A.M. 2015. A new species of Alterosa Blahnik (Trichoptera: Philopotamidae: Philopotaminae) from Espirito Santo State, southeastern Brazil. Zootaxa, 3931(4): 596-599.

Blahnik, R.J. 2005. Alterosa, a new caddisfly genus from Brazil (Trichoptera: Philopotamidae). Zootaxa, 991: 1-60.

Blahnik, R.J.; Holzenthal, R.W. \& Prather, A. 2007. The lactic acid method for clearing Trichoptera genitalia. In: International Symposium of Trichoptera, $12^{\circ}$. Proceedings. Columbus, Caddis. p. 9-14.

Dumas, L.L. \& Nessimian, J.L. 2012. Faunistic catalog of the caddisflies (Insecta: Trichoptera) of Parque Nacional do Itatiaia and its surroundings in southeastern Brazil. Journal of Insect Science, 12(25): 1-40.

Dumas, L.L. \& Nessimian, J.L. 2013. New species of the caddisfly genus Alterosa Blahnik 2005 (Trichoptera: Philopotamidae: Philopotaminae) from Brazil. Zootaxa, 3609(1): 26-48.

Dumas, L.L.; Calor, A.R. \& Nessimian, J.L. 2013. The genus Alterosa Blahnik 2005 (Trichoptera, Philopotamidae, Philopotaminae) in northeastern Brazil, including the description of three new species and an identification key for the genus. Zookeys, 317: 1-15.

Dumas, L.L.; Jardim, G.A.; Santos, A.P.M. \& Nessimian, J.L. 2009. Tricópteros (Insecta: Trichoptera) do Estado do Rio de Janeiro: Lista de espécies e novos registros. Arquivos do Museu Nacional, 67(3-4): 355-376.
Flint Jr., O.S. 1971. Studies of Neotropical Caddisflies, XII: Rhyacophilidae, Glossosomatidae, Philopotamidae and Psychomyiidae from the Amazon Basin (Trichoptera). Amazoniana, 3(1): 1-67.

Frost, S.W. 1957. The Pennsylvania Insect Light Trap. Journal of Economic Entomology, 50(3): 287-292.

Gibon, F. 2013. Une sous-famille caractéristique des forêts humides primaires malgaches: les Rossodinae (Trichoptera, Philopotamidae). Zoosystema, 35(2): 151-174.

Gressit, J.L. \& Gressit, M.K. 1962. An improved Malaise Trap. Pacific Insects, 4: 87-90.

Holzenthal, R.W. \& Calor, A.R. 2017. Catalog of the Neotropical Trichoptera (Caddisflies). Zookeys, 654: 1-566.

Holzenthal, R.W.; Blahnik, R.J. \& Ríos-Touma, B. 2018. New species and a new genus of Philopotamidae from the Andes of Bolivia and Ecuador (Insecta, Trichoptera). Zookeys, 780: 89-108.

Holzenthal, R.W.; Blahnik, R.J.; Prather, A.R. \& Kjer, K.M. 2007. Order Trichoptera Kirby, 1813 (Insecta), Caddisflies. Zootaxa, 1668: 639-698.

Jardim, G.A. \& Dumas, L.L. 2012. A new species of the genus Alterosa (Trichoptera: Philopotamidae) from Southeastern Brazil. Revista de Biologia Tropical, 60(2): 577-580.

McLachlan, R.F.L.S. 1865. Trichoptera Britannica; a Monograph of the British Species of Caddis-flies. Transactions of the Entomological Society of London, 5: 1-184.

Muñoz-Quesada, F.J. \& Holzenthal, R.W. 2015. Revision of the Neotropical species of the caddisfly genus Wormaldia McLachlan (Trichoptera: Philopotamidae). Zootaxa, 3998(1): 1-138.

Navás, L. 1918. Insecta nova. III Series. Memorie dell'Accademia Pontificia dei Nuovi Lincei, 4: 1-11.

Özdikmen, H. \& Darilmaz, M. 2008. New subfamily and genus names, Rossodinae nom. nov. and Rossodes nom. nov., for the finger-net caddisflies (Trichoptera: Philopotamidae). Munis Entomology and Zoology Journal, 3(1): 162-164.

Tillyard, R.J. 1924. Studies of New Zealand Trichoptera, or Caddis-flies: No 1, Description of a New Genus and Species belonging to the Family Sericostomatidae. Transactions of the New Zealand Institute, 53:346-350. 